Article

\title{
Development of a Novel Polymer-Based mRNA Coating for Surgical Suture to Enhance Wound Healing
}

\author{
Antonia Link ${ }^{1}$, Hanna Haag ${ }^{1}$, Tatjana Michel ${ }^{1}$, Markus Denzinger ${ }^{2}$, Hans Peter Wendel ${ }^{1}$, \\ Christian Schlensak ${ }^{1}$ and Stefanie Krajewski ${ }^{1, *(D)}$ \\ 1 Clinical Research Laboratory, Department of Thoracic and Cardiovascular Surgery, University Medical \\ Center, 72076 Tuebingen, Germany; antonia.link@uni-tuebingen.de (A.L.); \\ hanna.haag@klinikum.uni-tuebingen.de (H.H.); tatjana.michel@uni-tuebingen.de (T.M.); \\ hans-peter.wendel@med.uni-tuebingen.de (H.P.W.); christian.schlensak@med.uni-tuebingen.de (C.S.) \\ 2 Department of Plastic Surgery, BG Trauma Center, 72076 Tuebingen, Germany; m.denzinger@t-online.de \\ * Correspondence: stefanie.krajewski@uni-tuebingen.de; Tel.: +49-(0)7071-2983303
}

Received: 30 April 2019; Accepted: 4 June 2019; Published: 8 June 2019

\begin{abstract}
A therapeutic strategy to improve wound healing has become an increasingly important medical task due to the rising incidence of adiposity and type II diabetes as well as the proceeding population aging. In order to cope with the resulting burdens, new strategies to achieve rapid and complete wound healing must now be developed. Accordingly, the development of a bioactive wound dressing in the form of a messengerRNA (mRNA)-bearing poly(lactide-co-glycolide acid) (PLGA) coating on surgical suture is being pushed further with this study. Furthermore, the evaluation of the polymer-based transfection reagent Viromer RED has shown that it can be used for the transfection of eukaryotic cells: The mRNA gets properly complexed and translated into a functional protein. In addition, the mRNA-PLGA coating triggered the expression of the keratinocyte growth factor (KGF) in HaCat cells although KGF is not expressed under physiological conditions. Moreover, transfection via surgical sutures coated with mRNA does not affect the cell viability and a proinflammatory reaction in the transfected cells is not induced. These properties make the mRNA-PLGA coating very attractive for the in vivo application. For the future, this could mean that through the use of mRNA-coated sutures in surgical wound closure, cells in the wound area can be transfected directly, thus accelerating and improving wound healing.
\end{abstract}

Keywords: messengerRNA; poly(lactic-co-glycolic acid); surgical suture; coating; wound healing; keratinocyte growth factor

\section{Introduction}

In industrialized nations, the incidence of obesity and type II diabetes continues to increase as society simultaneously grows older [1]. In Germany alone, 2.5\% of the population suffers from chronic wounds with rising tendencies [2]. Furthermore, chronic wounds are, on the one hand, a major burden for the person concerned and, on the other hand, they pose a socio-economic challenge: About $2 \%$ of the health budget must be raised each year to treat poorly healing wounds [3]. Therefore, in order to cope with the enormous financial burden, new strategies must be developed for achieving rapid and complete wound healing. Moreover, wound healing is a complex three-stage process mediated by a large number of molecules such as different enzymes, cytokines, and growth factors [4]. Since the process of wound healing is determined by the nature of the wound, the healing prospects are best with smooth and closely adjacent wound edges [5]. Therefore, surgical sutures are used for wound closure to achieve this state whenever tissue separation occurs due to an incision, puncture, abrasion, or other injuries [6]. 
Additionally, sutures can consist of natural or synthetic textile biomaterials and they can be either monofilament with a smooth surface or braided to a multifilament structure $[7,8]$. The sutures' physical and mechanical properties, handling properties, biocompatibility, and antimicrobial characteristic are of utmost importance [9]. Moreover, various types of research have provided good anesthetic and antineoplastic properties to the surgical threads [6]. Consequently, several groups have incorporated different antimicrobial agents into sutures to impart microbe resistance characteristics and prevent infections at the surgical site $[10,11]$. A suture modification that promotes wound healing by triggering cell differentiation and proliferation in the wound area had not been introduced until now. The growth factor KGF plays an important role in wound healing because it stimulates the differentiation and proliferation of epithelial cells and conveys an anti-apoptotic effect [12]. Therefore, the idea is to trigger the expression of the growth factor by the body's own cells directly in the wound area via transfection of in vitro transcribed mRNA. This therapy works by delivering a modified mRNA encoding for the desired protein in order to target cells, which then translate the mRNA into the corresponding protein $[13,14]$. Accordingly, mRNA-based technology is already in use for the development of vaccines against different medical conditions, different cancer types, and monogenetic diseases. The mRNA therapy has several advantages over the DNA-based gene therapy where a permanent change in the genome is achieved. Moreover, with no risk of wrongly localized integration in the host genome, which could lead to mutagenic effects, the transfection efficiency is not dependent on the cell cycle and the synthesis of the desired protein occurs fast through the cells own translational machinery under physiological conditions that can be controlled $[15,16]$.

Since mRNA is a relatively large molecule, no transporter proteins are available for transportation through the cell membrane. Therefore, in order to initiate the mRNA transfer, various physical, biological, or chemical methods exist, each of which has specific advantages and disadvantages. Additionally, since chemical transfection methods are the most common, cationic polymers such as polyethylenimine (PEI) or cationic lipids/lipid mixtures such as Lipofectamine 2000 are used [17-19]. This method is based on the principle that positively charged polymer or lipid particles form complexes with negatively charged nucleic acids and prevent the mRNA from nucleases digesting it in extracellular space [20]. Subsequently, these positively charged complexes are attracted to the cell membrane and the uptake is conducted via endocytosis. After absorption, the carrier molecules are broken down and the mRNA is released in the cytoplasm, where it can be translated into a protein [21]. However, the transfections of cells with cationic reagents lead to rapid mRNA intake and translation with the peak in protein translation after $24 \mathrm{~h}$. As a result, it is crucial to guarantee continuous therapeutic protein production for the treatment of chronical wounds.

Furthermore, PLGA-based delivery systems enable targeted and controllable local drug release [22] and lay the foundation stone for the development of a bioactive coating for multifilament seam material: A polymer-based mRNA-PLGA coating should enable the in vivo transfection of cells in the wound area. In order to immobilize the encapsulated mRNA encoding for the desired protein, the approach is to set up a coating on the surface of surgical suture based on PLGA. Accordingly, the copolymer can be well degraded by eukaryotic cells while showing good compatibility with tissue and cells without bearing any toxic effects. Due to these positive characteristics, PLGA is one of the few polymers that have been approved by the Food and Drug Administration (FDA) for clinical use in humans [23]. Therefore, PLGA is widely used to produce extended release formulations (for encapsulation of drug substances) and implants with adjustable properties for local delivery [24,25].

To our knowledge, we are the first group to have established a novel mRNA-based coating for surgical suture material. This is intended to transfect cells in the wound area and, thus, improve wound healing through the expression of the growth factor KGF. Therefore, therapeutic KGF-encoding mRNA with a suitable transfection agent was incorporated into a PLGA coating. In doing so, the coating should degrade as well as release and translate mRNA in a constant manner. Thus, physiological processes such as wound healing can be improved and remodeled through the targeted expression of growth factors [26]. 


\section{Materials and Methods}

\subsection{Cell Culture}

As human skin is mainly made up of fibroblasts and keratinocytes, the human keratinocyte cell line HaCat (CLS Cell Lines Service Inc, Eppelheim, Germany) and BJ fibroblast (ATCC, Manassas, VA, USA) from human foreskin were used in this study. The HEK293 cell line was used as a control. All cells were grown in $175 \mathrm{~cm}^{2}$ cell culture flasks at $37^{\circ} \mathrm{C}$ and $5 \% \mathrm{CO}_{2}$. HaCat or HEK293 cells were cultured in Dulbecco's modified Eagle's medium (DMEM; Thermo Fisher Scientific Inc., Karlsruhe, Germany) supplemented with 10\% fetal bovine serum (FBS; Thermo Fisher Scientific Inc) and 1\% penicillin/streptomycin (Thermo Fisher Scientific Inc.). For BJ fibroblast cultivation, 3\% HEPES-buffer (1 M; Gibco by life technologies Inc., Darmstadt, Germany) was further added. When cells reached $90 \%$ confluency, they were trypsinized with $0.25 \%$ trypsin in buffered ethylenediaminetetraacetic acid (EDTA) (Thermo Fisher Scientific Inc.). Cell detachment was stopped using the corresponding cell culture medium. Cells were centrifuged at $300 \mathrm{~g}$ for $5 \mathrm{~min}$ and resuspended. Afterwards, cells were counted with the CASY cell counter (Roche Diagnostics Inc., Mannheim, Germany).

For each experiment, cells were seeded with different density onto a 12-well plate: HEK293 cells were seeded at $1.0 \times 10^{5}$ cells/well, keratinocytes at $1.5 \times 10^{5}$ cells/well, and BJ fibroblasts at $0.75 \times 10^{5}$ cells/well. All cells were seeded 1 day prior to transfection.

\section{2. $m R N A$ Synthesis}

mRNAs encoding for enhanced green fluorescent protein (eGFP) and KGF were generated using a procedure previously described [14]. This multi-step procedure starts with amplification of the DNA templates of eGFP or KGF, which are encoded in the associated pcDNA 3.3 plasmids (Eurofins Genomics Inc., Ebersberg, Germany). The amplification was conducted via polymerase chain reaction (PCR) by using the HotStar HiFidelity Polymerase Kit (Qiagen Inc., Hilden, Germany) according to manufacturer's instruction (TTGGACCCTCGTACAGAAGCTAATACG as forward primer and $\mathrm{T}_{120}$ CTTCCTACTCAGGCTTTATTCAAAGACCA as reverse primer (Ella Biotech Inc., Martinsried, Germany)). The in vitro transcription (IVT) of DNA to mRNA was performed by using the T7 MEGAscript Kit (Life Technologies Inc., Carlsbad, CA, USA). The mRNA was modified by attaching a 3'-0-Me-m7G(5')ppp(5')G RNA Cap Structure Analog (New England Biolab, Inc., Ipswich, UK) as well as adding pseudouridine-5' -triphosphate and 5-methylcytidine-5' ${ }^{\prime}$-triphosphate (TriLink Biotech Inc., San Diego, CA, USA) to the reaction, which were substitutes for UTP and CTP. The in vitro transcripted mRNA was dephosphorilized using the Antarctic Phosphatase Kit (New England Biolab Inc.,) and purified with the RNeasy Kit (Qiagen Inc.).). The nucleic acid products of PCR and IVT were controlled with gel electrophoresis using a 1\% agarose-TBE gel.

\subsection{Coating of Multifilament Suture with mRNA and PLGA following Transfection of Cells}

In this study, PLGA was used to immobilize complexed mRNA on multifilament seam material and to achieve transfection of cells by degradation of the coating and release of mRNA. In the first step, a stock solution was prepared by dissolving $20 \mathrm{mg}$ PLGA (Evonik Inc., Essen, Germany) in $1000 \mu \mathrm{L}$ of ethyl acetate (Honeywell Riedel-de Haën Inc., Seelze, Germany). This stock solution was sterile-filtered and stored at $+4{ }^{\circ} \mathrm{C}$. Before each experiment, $10 \mu \mathrm{L}$ of the stock solution was diluted with $990 \mu \mathrm{L}$ of sterile ethyl acetate as a working solution. For the coating, the mRNA was complexed with either Viromer RED (Lipocalyx Inc., Halle (Saale), Germany) or Lipofectamine 2000 (Invitrogen Inc., Carlsbad, CA, USA) as a transfection agent. For the Viromer RED-based coating, $0.5 \mu \mathrm{L}$ of the transfection agent was placed in a reaction tube and mixed with $12 \mu \mathrm{L}$ Viromer RED buffer solution. Next, mRNA was added, so the resulting concentration was $1 \mu \mathrm{g}$ mRNA per $15 \mu \mathrm{L}$. Complex formation occurred during $15 \mathrm{~min}$ incubation at room temperature (RT). For the Lipofectamine 2000-based coating, $0.5 \mu \mathrm{L}$ Lipofectamine 2000 was mixed with $12 \mu \mathrm{L}$ Opti-MEM I medium (Invitrogen Inc.) and $2.5 \mu \mathrm{g}$ mRNA, and incubated for $20 \mathrm{~min}$ at RT. After complex formation, $15 \mu \mathrm{L}$ of each transfection solution was 
mixed with $20 \mu \mathrm{L}$ of the PLGA utility solution. A $1 \mathrm{~cm}$ piece of multifilament suture was placed on a glass slide and the mRNA PLGA solution was added drop by drop. When the solvent ethyl acetate evaporated and the filaments were dry, they were turned, and the other side was coated by dropwise adding of the mRNA-PLGA solution. This procedure was repeated until the entire coating solution was applied to the suture. According to this procedure, $1 \mu \mathrm{g}$ mRNA should be immobilized on the seam material. In order to increase the amount of mRNA immobilized on the surface, the volume of the coating solution was increased proportionally. The coated filament was put on the cells in the 12-well plates and incubated at $37^{\circ} \mathrm{C}$ and $5 \% \mathrm{CO}_{2}$ until analysis. Seam material coated with only PLGA or PLGA and the transfection agent were used as controls. The transfection efficiency of the coated suture was compared to that of direct cellular transfection. For this purpose, $15 \mu \mathrm{L}$ of the mRNA, which was complexed with Viromer RED, was taken from the same transfection mixture as the one used for the coating and added directly to the cell culture medium of the cells. For comparing the direct and indirect transfection efficiency of mRNA, which was complexed with Lipofectamine 2000, the cells were first washed twice with $1000 \mu \mathrm{L}$ PBS buffer (w/o Ca ${ }^{+} / \mathrm{Mg}^{+}$) (Gibco by life technologies Inc.). Then, $15 \mu \mathrm{L}$ of the already prepared Lipofectamine 2000 transfection solution was taken and mixed with $500 \mu \mathrm{L}$ Opti-MEM I and added drop by drop to the cells. After $4 \mathrm{~h}$ of incubation, the transfection complexes were removed, and cells were cultured in full medium until analysis. Cells incubated with the transfection agent only were used as a control.

\subsection{Scanning Electron Microscopy}

To be able to visualize the structure of the mRNA-PLGA coating applied to the surgical suture after the coating process, the suture had to be prepared for scanning electron microscope (SEM) analysis. To remove the remaining water, the samples were incubated in ethanol p.A. (Merck Inc., Darmstadt, Germany) with increasing concentration of $40 \%-100 \%$. Finally, the samples were dried using a desiccator, then sputtered with gold palladium, and subsequently analyzed with SEM (Cambridge Instruments Inc., Cambridge, UK).

\subsection{KGF Enzyme-Linked Immunosorbent Assay}

To quantify the amount of KGF expressed by the cells after mRNA transfection, the supernatant was analyzed using the KGF-ELISA (human FGF-7 enzyme-linked immunosorbent assay kit, Sigma-Aldrich Inc., St Louis, MO, USA). The assay was performed according to the specifications of the manufacturer.

\subsection{Flow Cytometry}

Flow cytometric analyses of the transfected HEK293, HaCat, and BJ fibroblasts were performed to determine the level of eGFP-expressing cells. Thus, $24 \mathrm{~h}$ or $48 \mathrm{~h}$ post transfection, cells were detached from 12-well plates, washed with PBS (w/o Ca ${ }^{+} / \mathrm{Mg}^{+}$), and fixed using $250 \mu \mathrm{L} 1 \mathrm{x}$ CellFix (BD Biosciences Inc., Franklin Lakes, NJ, USA). Flow cytometry was performed using a FACScan cytometer (BD Biosciences Inc.). For each sample, a total of 10,000 events were acquired. Fluorescence microscopic analyses were performed before cell detachment.

\subsection{Real-Time $q P C R$}

To determine how the transfection of $1 \mu \mathrm{g}$ KGF mRNA impacts the gene expression of inflammatory markers in primary fibroblasts $6 \mathrm{~h}$ or $24 \mathrm{~h}$ post transfection, the total RNA of the cells was isolated using the Aurum total RNA isolation kit (Bio-Rad Laboratories Inc., München, Germany). The isolated RNA was converted to copy DNA (cDNA) using the iScript kit (Bio-Rad Laboratories Inc.). Expression of interferon alpha (IFN- $\alpha$ ), interferon beta (IFN- $\beta$ ), and tumor necrosis factor alpha (TNF- $\alpha)($ IFN- $\alpha$ : Forward Primer $5^{\prime}$-ACC CCT GCT ATA ACT ATG ACC ATG C- $3^{\prime}$, Reverse Primer $5^{\prime}$-CAC AGT GTA AAG GTG CAC ATG ACG-3'; IFN- $\beta$ : Forward Primer $5^{\prime}$-TAC CTG AAG GCC AAG GAG TAC AG-3', Reverse Primer $5^{\prime}$-CGG AGG TAA CCT GTA AGT CTG TTA A-3'; TNF- $\alpha$ : Forward Primer $5^{\prime}-\mathrm{CCC}$ AGG CAG TCA GAT CAT CTT C-3', Reverse Primer 5'-GTT ATC TCT CAG CTC CAC GCC-3' (Ella 
Biotech Inc.)) was analyzed. Glyceraldehyde 3-phosphate dehydrogenase (GAPDH) expression was used as reference (Forward Primer 5'-TCA ACA GCG ACA CCC ACT CC- $3^{\prime}$, Reverse Primer $5^{\prime}$-TGA GGT CCA CCA CCC TGT TG-3' (Ella Biotech Inc.)). The real-time qPCR was performed using the CFX Connect Real-Time PCR detection system (Bio-Rad Laboratories Inc.).

\subsection{Cell Viability Assay}

The colorimetric MTT assay, which is based on the glycolysis-dependent conversion of the yellow tetrazolium salt 3-(4.5-dimethyl-2-thiazolyl)-2.5-diphenyl-2H-tetrazolium bromide (MTT; AppliChem Inc., Darmstadt, Germany) to violet formazan, was used to determine cell metabolic activity and viability. Cells were washed three times with RPMI without phenol red (Life technologies Inc.) and incubated for $4 \mathrm{~h}$ at $37^{\circ} \mathrm{C}$ with $330 \mu \mathrm{L}$ of a $0.05 \%$ solution of MTT. Afterwards, the MTT solution was removed and $300 \mu \mathrm{L}$ DMSO (dimethyl sulfoxide; Serva Inc., Heidelberg, Germany) were added to dissolve the generated formazan. The absorbance of the DMSO solution was measured at $540 \mathrm{~nm}$ with the Mithras LB 940 Microplate Reader (Berthold technologies Inc., Bad Wildbad, Germany).

\subsection{Hemocompatibility Testing}

For hemocompatibility testing, blood samples of four healthy donors were collected by venipuncture. This procedure is approved by the Ethics Committee of the medical faculty at the University of Tübingen (Project identification code: 270/2010BO1) and all subjects gave their written informed consent for inclusion before they participated in the study. The study was conducted in accordance with the Declaration of Helsinki. The collected blood samples were anticoagulated with $1.5 \mathrm{IU}$ heparin/ mL blood (LEO Pharma Inc., Neu-Isenburg, Germany) and the intake of hemostasis-affecting drugs within the last 14 days, oral contraceptives, and smoking were set as exclusion criteria to guarantee uninfluenced clotting behavior.

To prove whether the mRNA-PLGA coating on the suture does not affect blood clotting, baseline values of several hemocompatibility markers were gained by directly transferring the heparinized blood after blood draw into three different monovettes containing either EDTA (Sarstedt Inc., Nümbrecht, Germany), CTAD (BD Biosciences Inc.), a mixture of citrate, theophylline, adenosine, and dipyridamole, or citrate (Sarstedt Inc.). Coated pieces of suture $(3 \mathrm{~cm})$ were incubated with $9 \mathrm{~mL}$ of fresh human blood in round polypropylene bottom tubes (BD Biosciences Inc.) at $37^{\circ} \mathrm{C}$ for $60 \mathrm{~min}$ under dynamic conditions. A tube filled with just $9 \mathrm{~mL}$ of blood was used as a control. After incubation, the blood was transferred into the respective monovettes, containing EDTA, CTAD, or citrate. Blood anticoagulated with EDTA was first used to draw a hemogram, while afterwards, all blood samples were centrifuged followed by blood plasma collection. Plasma samples were stored at $-20^{\circ} \mathrm{C}$ or $-80^{\circ} \mathrm{C}$ until the analysis of various hemocompatibility markers. ELISAs were performed to quantify thrombin-antithrombin-complex (Enzygnost@TAT micro-Siemens Healthcare Inc., Marburg, Germany), Polymorphonuclear (PMN) elastase (Demeditec Diagnostics Inc., Kiel, Germany), $\beta$-thromboglobulin (Stago Inc., Düsseldorf, Germany), and SC5b9-complex (Tecomedical Inc. Sissach, Switzerland).

\subsection{Statistics}

All data are given as means with standard error of the mean (SEM). To test normal distribution, the Kolmogorov-Smirnov test was used. Normally distributed datasets were analyzed using one-way or repeated measures (RM) ANOVA with Bonferroni's multiple comparison test to analyze differences between groups. The Kruskal-Wallis test was used for non-normal distributed datasets. All analyses were performed using the statistical software package GraphPad Prism version 6 (GraphPad Software Inc., La Jolla, CA, USA). Statistical significance was defined as $p<0.05$. 


\section{Results}

\subsection{Evaluation of a suitable Transfection Agent for the Construction of a mRNA Coating for Seam Material}

During previous studies, it could be shown that mRNA can be delivered to cells with a variety of different transfections agents, all leading to the expression of a functional protein. For the present study, it was important to check whether the complexed mRNA could be incorporated into a coating made up of PLGA (Figure 1a). The resulting coating is extensively spread on the surface of the suture (Figure 1b,c) and ought to work as a carrier system that transfects epithelial cells with growth factor-encoding mRNA and, thus, improves wound healing.

(a)

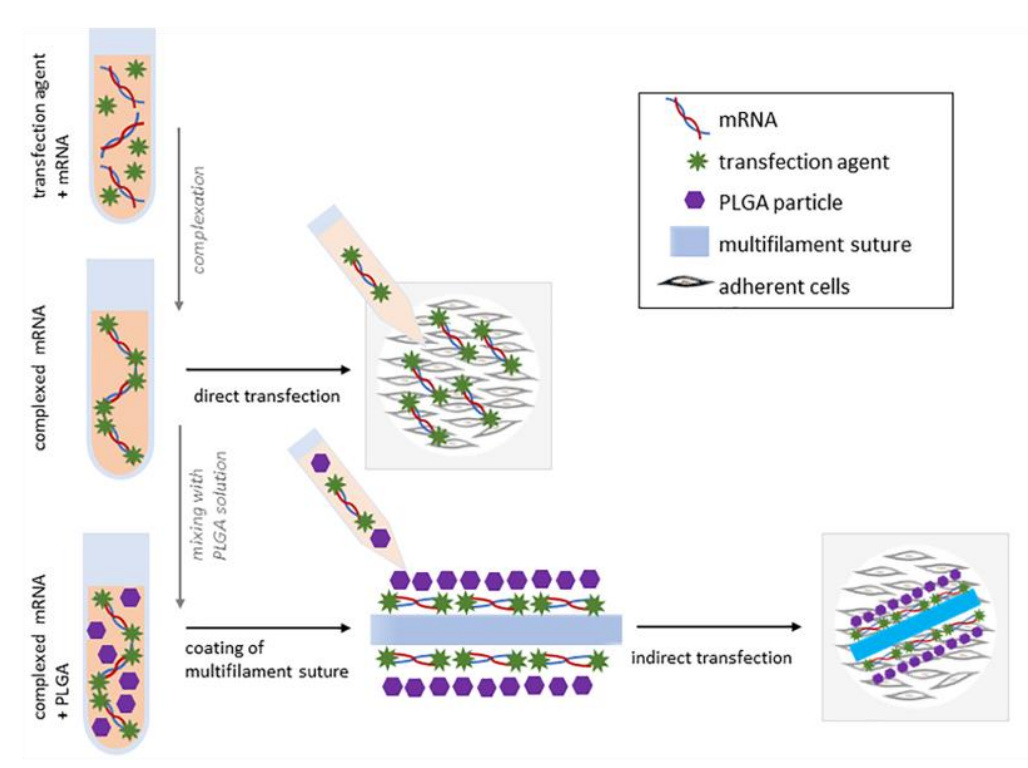

(b)

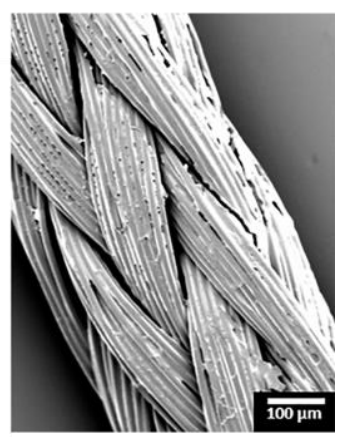

(c)

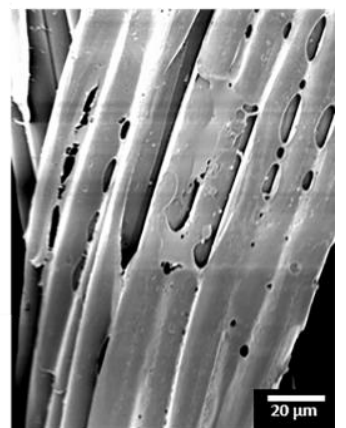

Figure 1. Schematic overview of the coating process and microscopic view of the coating. After complexation of a specific mRNA, cells can either be transfected in a direct manner or the complexed mRNA can be mixed with a PLGA solution followed by coating of multifilament sutures and subsequent indirect transfection (a). Scanning electron microscope visualization of the surface of the mRNA-PLGA coated multifilament suture in 100-fold (b) and 500-fold (c) magnification.

In order to evaluate whether Viromer RED or Lipofectamine 2000 is more suitable to build a functional mRNA-PLGA coating, HEK293 cells were transfected with $1 \mu \mathrm{g}$ eGFP mRNA either by direct transfection or by coated sutures.

To assess the efficiency of transfection, the transfected HEK293 cells were analyzed 24 and $48 \mathrm{~h}$ post transfection by flow cytometry (Figure $2 \mathrm{a}, \mathrm{b}$ ). After $24 \mathrm{~h}, 86.35 \% \pm 1.55 \%$ of the cells transfected with Viromer RED directly expressed eGFP while only 34.92\% $\pm 4.16 \%$ of the cells transfected with Lipofectamine $2000 \mathrm{did}$. After $48 \mathrm{~h}$, the percentage of eGFP-expressing cells after Viromer RED treatment was nearly stable $(87.45 \% \pm 1.85 \%)$, while the number of cells producing eGFP after transfection with Lipofectamine 2000 slightly increased to $49.11 \% \pm 5.09 \%$ (Figure 2a). When it came to transfection via the coated sutures, the Viromer RED based coating was able to transfect $29.11 \% \pm 1.16 \%$ of HEK293 cells after $24 \mathrm{~h}$ and the eGFP expression remained stable for another $24 \mathrm{~h}(29.59 \% \pm 2.24 \%)$. The coating made up of Lipofectamine 2000 could not trigger a detectable eGFP expression: $0.4 \% \pm 0.29 \%(24 \mathrm{~h})$ or $1.12 \% \pm 0.39 \%(48 \mathrm{~h}$ ) of HEK293 cells were recognized as fluorescent. This is roughly the same percentage as the non-transfected HEK293 cells $(0.69 \% \pm 0.37 \%)$ (Figure $2 b)$. 
(a)

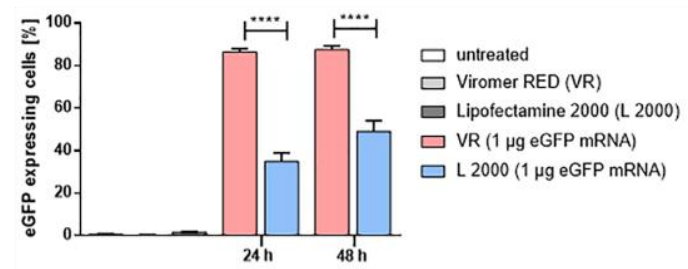

(b)

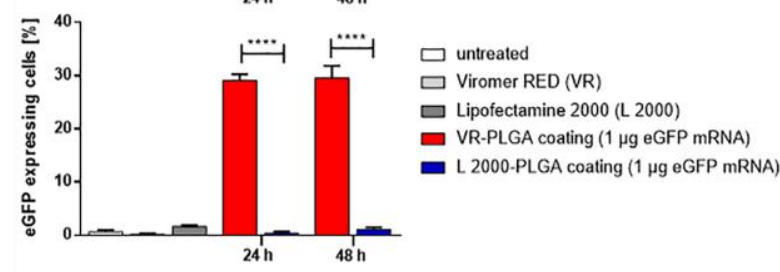

(c)

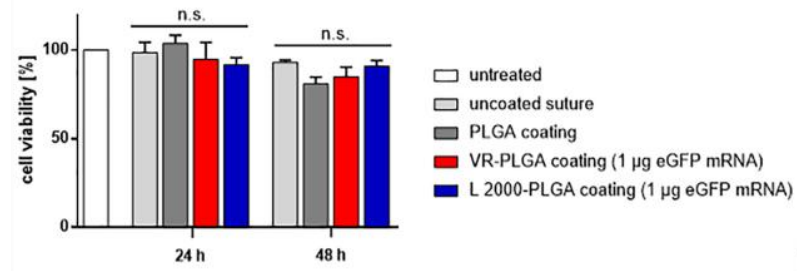

(d)

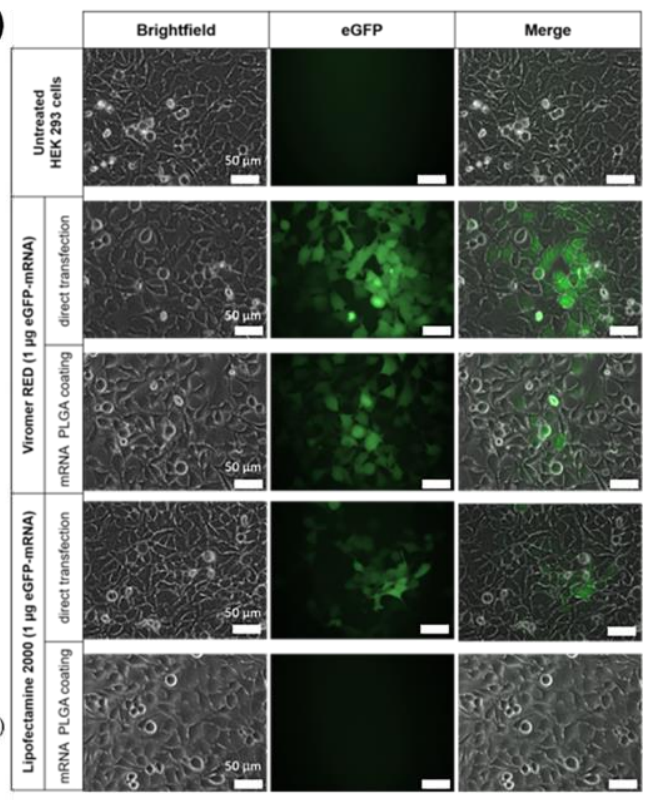

Figure 2. Comparison of different cationic transfection reagents for direct and indirect mRNA transfection of cells. Flow cytometric analysis of eGFP mRNA-transfected HEK293 cells using Viromer RED and Lipofectamine 2000 for direct transfection (a) or transfection via mRNA-PLGA coated sutures (b) 24 and $48 \mathrm{~h}$ post transfection $\left(n=4{ }^{* * * *} p<0.0001\right)$. Determination of cell viability after exposition to different kinds of suture for 24 or $48 \mathrm{~h}(\mathrm{c})(n=4$; n.s. = not significant). Fluorescence microscopic images of HEK293 cells $48 \mathrm{~h}$ after transfection by direct addition of $1 \mu \mathrm{g}$ of complexed mRNA or mRNA-coated sutures $(\mathbf{d})$.

To exclude cytotoxic effects of coated sutures on HEK293 cells, a cell viability assay was performed (Figure 2c). The cells were subjected to the sutures over periods of 24 and $48 \mathrm{~h}$, respectively. Untreated cells were used as a reference and their viability was set to $100 \%$. For comparison, uncoated and PLGA-only-coated suture materials were used as well as mRNA- and PLGA-coated sutures either using Viromer RED or Lipofectamine 2000 as a transfecting agent. Within 48 h, no significant reduction in cell viability of the HEK293 cells, exposed to different kinds of suture, could be detected.

The results of flow cytometry could be confirmed by analysis with fluorescent microscopy $48 \mathrm{~h}$ post transfection (Figure 2d). The direct transfection with Viromer RED led to visible more eGFP-expressing cells than Lipofectamine 2000. An indirect transfection via a mRNA-PLGA coating was only successful when using Viromer RED.

\section{2. eGFP Transfection of Skin Cells by mRNA-Coated Seam Material}

Since fibroblasts and keratinocytes play an important role in the wound healing as they migrate from the surrounding tissue into the wound area and fill up the tissue defect, improvement in wound healing could be achieved if cells in the wound area are able to be transfected with therapeutic mRNA. The transfection can occur via seam material that is in contact with fibroblasts and keratinocytes in the case of a cutaneous wounds.

For this experiment, BJ fibroblasts and HaCat cells were transfected with different amounts of eGFP mRNA whether in a direct manner with Viromer RED-mRNA or through the mRNA-PLGA coating. Successful protein expression in cells after transfection was observed microscopically as well as quantified by flow cytometry.

When BJ fibroblasts were treated with eGFP mRNA, the direct transfection of $1 \mu \mathrm{g}$ mRNA led to a significantly higher percentage of protein expression than transfections performed with $2.5 \mu \mathrm{g}$ mRNA after $24 \mathrm{~h}$ (Figure 3a: 59.06\% $\pm 7.12 \%$ vs. 35.43\% $\pm 6.00 \%$ ). eGFP expression was regulated to a uniform level after $48 \mathrm{~h}$ incubation: Of the cells transfected with $1 \mu \mathrm{g}$ mRNA, $34.37 \% \pm 2.74 \%$ expressed the 
fluorescent protein and $32.05 \% \pm 5.58 \%$ of the fibroblasts transfected with $2.5 \mu \mathrm{g}$ mRNA did. The direct transfection of HaCat cells with different amounts of mRNA led to no significant differences regarding the transfection efficiency: After $24 \mathrm{~h}, 57.14 \% \pm 1.17 \%$ and $59.85 \% \pm 5.44 \%$ of the cells transfected with 1 and $2.5 \mu \mathrm{g}$ eGFP mRNA, respectively, expressed the fluorescent protein (Figure 3b). After $48 \mathrm{~h}$ of incubation, the number of eGFP-expressing cells was significantly reduced to $35.78 \% \pm 6.68 \%(1 \mu \mathrm{g}$ mRNA) and $31.78 \% \pm 6.65 \%(2.5 \mu \mathrm{g}$ mRNA $)$ in both treatment groups.

(a) BJ fibroblasts

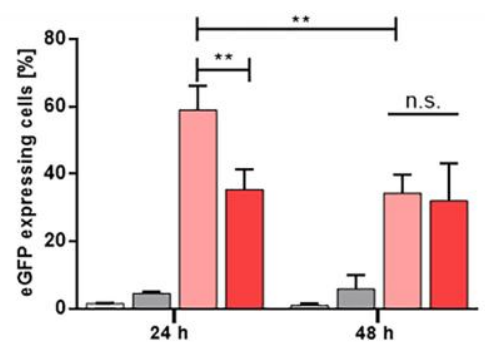

(c) BJ fibroblasts

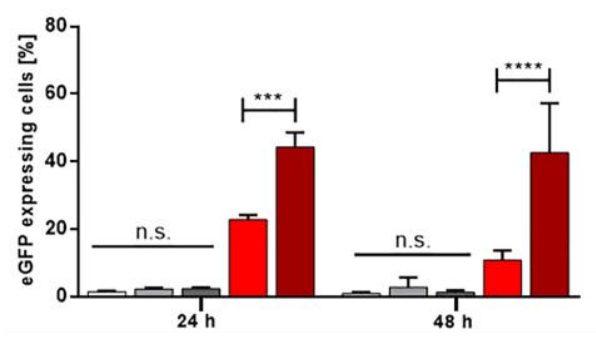

(b) HaCat cells

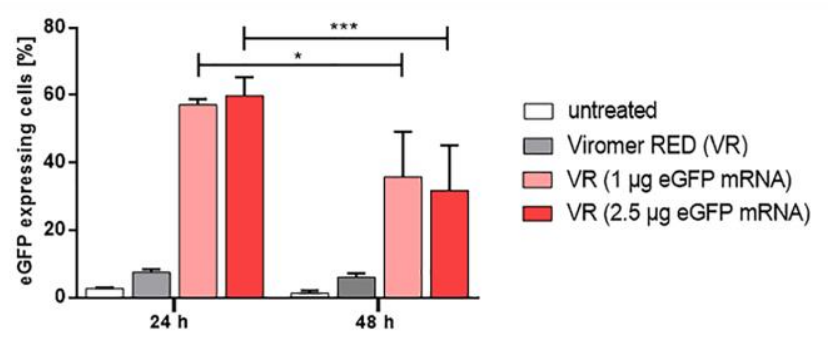

(d) HaCat cells

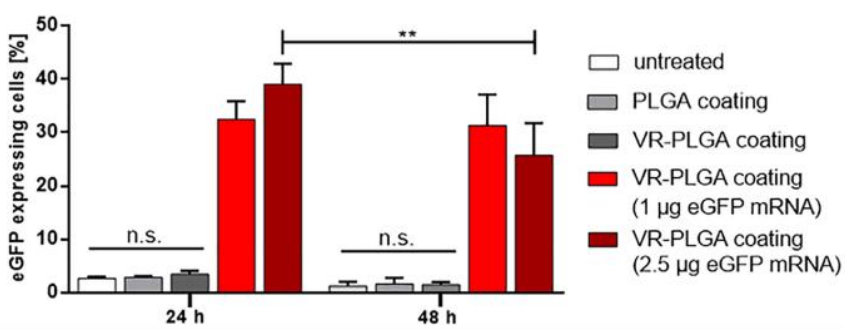

Figure 3. Determination of the transfection efficiencies 24 or $48 \mathrm{~h}$ after direct or indirect eGFP mRNA transfection. Flow cytometric analysis 24 or $48 \mathrm{~h}$ after the direct transfection of BJ fibroblasts (a) or HaCat cells (b) with Viromer RED-encapsulated eGFP-encoding mRNA. BJ fibroblasts (c) and HaCat cells (d) were also analyzed after the indirect transfection via the mRNA-PLGA coating $(n=4 ; * * * * p<0.0001$, $* * * p<0.001,{ }^{* *} p<0.01,{ }^{*} p<0.05$, n.s. $=$ not significant $)$.

After transfection of BJ fibroblasts via the PLGA coating containing $1 \mu \mathrm{g}$ mRNA, $22.78 \% \pm 1.47 \%$ of the cells expressed eGFP after $24 \mathrm{~h}$. After another $24 \mathrm{~h}$, the percentage of eGFP-expressing cells decreased to $10.82 \% \pm 1.41 \%$ (Figure $3 c$ ). Transfection via the mRNA-PLGA coating that contained $2.5 \mu \mathrm{g}$ eGFP mRNA was significantly more effective, since $44.26 \% \pm 4.30 \%$ of the cells expressed the fluorescent protein after $24 \mathrm{~h}$. Also, there was no significant reduction in eGFP expression $(42.55 \% \pm 7.34 \%)$ after $48 \mathrm{~h}$ of incubation. When the transfection of HaCat cells was performed via the PLGA coating, similar effects of protein expression could be observed: After $24 \mathrm{~h}$, no significant difference between the different coatings had occurred (Figure $3 \mathrm{~d}$ : $32.50 \% \pm 3.35 \%$ for $1 \mu \mathrm{g}$ mRNA vs. $39.08 \% \pm 3.87 \%$ for $2.5 \mu \mathrm{g}$ mRNA). The coating containing $1 \mu \mathrm{g}$ eGFP mRNA led to a stable eGFP expression over $48 \mathrm{~h}$, while the number of eGFP-expressing cells significantly declined when using the coating containing $2.5 \mu \mathrm{g}$ of mRNA.

\subsection{Induction of therapeutic Protein Expression by KGF mRNA-Coated Sutures}

During wound healing, keratinocytes play an important role: They ensure reepithelialization of the damaged skin layer by migrating into the wound area, whereby this process is stimulated by KGF. An artificial increase of KGF in the wound area, triggered by cell transfection via a mRNA-PLGA coating, could, thus, improve cell proliferation and wound healing.

For the quantification of secreted therapeutic KGF protein BJ fibroblasts and HaCat cells were transfected with different amounts of KGF mRNA through a Viromer RED based mRNA-PLGA coating and the protein level was analyzed in the supernatants using KGF-ELISA. 
The direct transfection of BJ fibroblasts with $1 \mu \mathrm{g}$ of KGF mRNA resulted in a secretion of $135.2 \pm 37.44 \mathrm{ng} / \mathrm{mL}$ KGF protein during the first $24 \mathrm{~h}$ post transfection, whereas after $48 \mathrm{~h}$, the KGF expression decreased to a level of $52.06 \pm 17.72 \mathrm{ng} / \mathrm{mL}$ (Figure 4a). The indirect transfection via the mRNA-PLGA coating led to the expression of $42.23 \pm 17.86 \mathrm{ng} / \mathrm{mL}$ for $1 \mu \mathrm{g}$ KGF mRNA and $44.33 \pm 7.44 \mathrm{ng} / \mathrm{mL}$ for $2.5 \mu \mathrm{g} \mathrm{KGF} \mathrm{mRNA} \mathrm{after} 24 \mathrm{~h}$. After $48 \mathrm{~h}$, the amount of released KGF decreased to $26.44 \pm 3.83 \mathrm{ng} / \mathrm{mL}$ and $25.71 \pm 1.19 \mathrm{ng} / \mathrm{mL}$ in the mRNA-PLGA suture groups containing 1 and $2.5 \mu \mathrm{g}$ KGF mRNA, respectively.
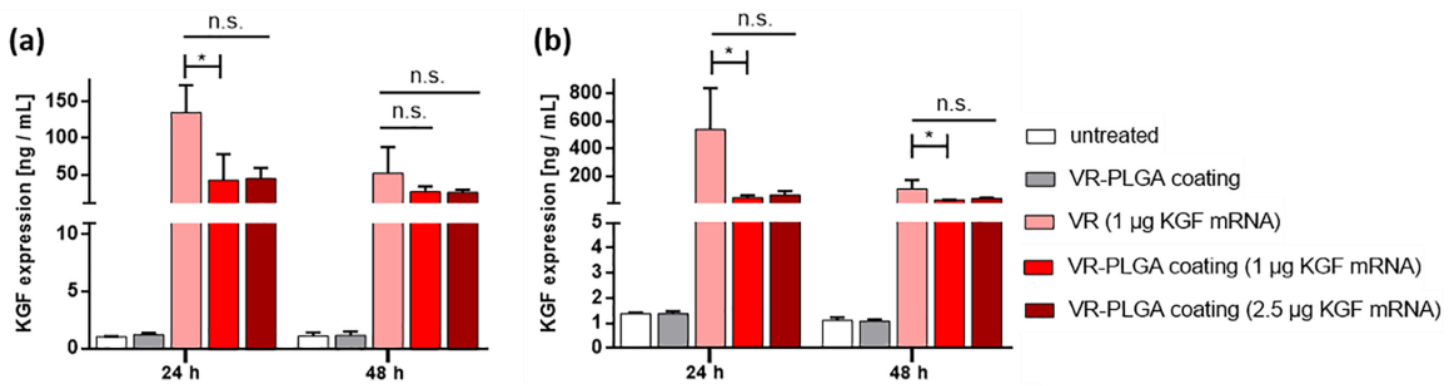

Figure 4. Quantification of the release of KGF protein after the in vitro incubation of cells with mRNA complexes of mRNA-coated sutures. Analysis of KGF secreted by BJ fibroblasts (a) or HaCat cells (b) 24 or $48 \mathrm{~h}$ after transfection via the mRNA-PLGA coating that contained either 1 or $2.5 \mu \mathrm{g}$ KGF-mRNA. For comparison, the amount of expressed KGF after the direct transfection with $1 \mu \mathrm{g}$ KGF mRNA was quantified $\left(n=4 ;{ }^{*} p<0.05\right.$, n.s. $=$ not significant $)$.

When HaCat cells were directly transfected with $1 \mu \mathrm{g}$ mRNA, a KGF concentration of $537.60 \pm 302.30 \mathrm{ng} / \mathrm{mL}$ was measured after $24 \mathrm{~h}$. The transfection via the coating bearing $1 \mu \mathrm{g}$ KGF mRNA led to a significantly lower amount of protein $(42.51 \pm 8.31 \mathrm{ng} / \mathrm{mL})$ though the transfection with $2.5 \mu \mathrm{g}$ mRNA in the coating resulted in increased protein levels of $62.35 \pm 14.46 \mathrm{ng} / \mathrm{mL}$ (Figure $4 \mathrm{~b}$ ). After $48 \mathrm{~h}$, the amount of secreted KGF following direct transfection decreased to $105.20 \pm 32.72 \mathrm{ng} / \mathrm{mL}$. HaCat cells that were transfected by a coating containing $1 \mu \mathrm{g}$ mRNA secreted $25.65 \pm 1.18 \mathrm{ng} / \mathrm{mL}$ KGF after $48 \mathrm{~h}$ and for the coating bearing $2.5 \mu \mathrm{g}$ mRNA, the measured KGF level after $48 \mathrm{~h}$ was $35.85 \pm 3.14 \mathrm{ng} / \mathrm{mL}$.

\subsection{Cytokine Release Post Transfection}

It is known that nucleic acids can stimulate the immune system by activating toll-like receptors (TLRs). Although immunogenicity can be reduced by using modified nucleotides in the in vitro synthesis of mRNA, potential immune reactions, which may be induced, must be excluded.

To determine the effect of the mRNA transfection on gene expression of inflammatory markers in BJ fibroblasts, the whole RNA content of the cells was isolated and prepared for quantitative real-time PCR $6 \mathrm{~h}$ and $24 \mathrm{~h}$ after transfection.

An expression of IFN- $\alpha$ could not be detected at any time in the fibroblasts (Figure $5 \mathrm{a}$ ). The direct transfection with $1 \mu \mathrm{g}$ KGF mRNA led to an increased expression of IFN- $\beta$ compared to the transfection via the PLGA coating $6 \mathrm{~h}$ and $24 \mathrm{~h}$ post transfection (Figure $5 \mathrm{~b}$ ). When it came to the expression of TNF- $\alpha$, the directly transfected fibroblasts showed increased gene expression compared to all other treatment groups (Figure $5 c$ ). 
(a)

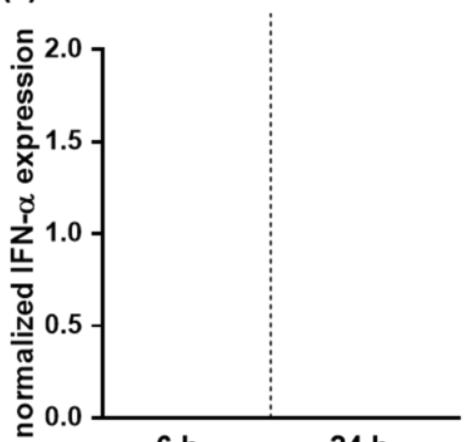

$6 \mathrm{~h}$ (b)

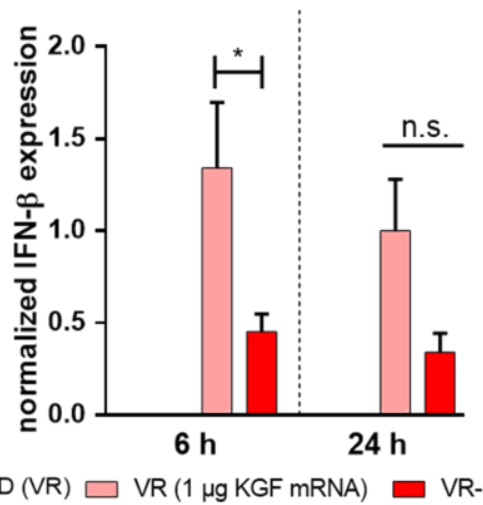

(c)

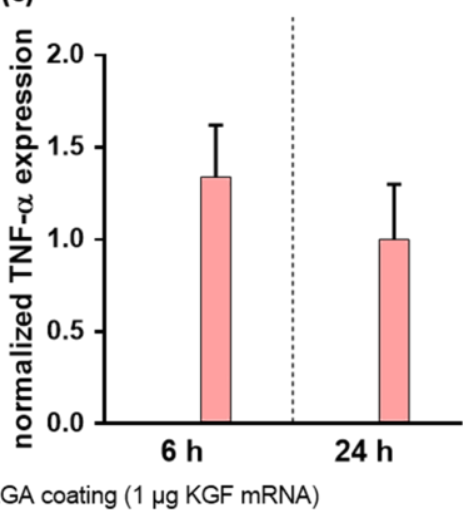

Figure 5. Analyses of different proinflammatory genes in BJ fibroblasts after transfection with therapeutic mRNA-complexes or mRNA-coated sutures. qRT-PCR was used to determine the release of interferon alpha (a), interferon beta (b), and tumor necrosis factor alpha (c) $6 \mathrm{~h}$ and $24 \mathrm{~h}$ post transfection. The expression pattern of untreated cells was compared to the one of cells treated with Viromer RED only, cells transfected with $1 \mu \mathrm{g}$ KGF mRNA in a direct manner, or transfected via the mRNA-PLGA coating containing $1 \mu \mathrm{g}$ KGF mRNA. $(n=4 ; * p<0.05$, n.s. $=$ not significant).

\subsection{Hemocompatibility of KGF-Encoding mRNA-PLGA Seam Material}

The ability of the mRNA-coated sutures to interact with blood coagulation or the complement cascades plays a pivotal role for its potential use in clinical applications. To analyze whether the mRNA-PLGA coating influences hematological processes, sutures with different coatings were incubated with heparinized, fresh human whole blood and blood cell count, as well as various hematological markers were determined using specific ELISAs.

It could be shown that neither the PLGA coating alone nor in combination with Viromer RED or KGF-encoding mRNA had a measurable effect on the blood. When examining the blood cell count before and after incubation, no differences regarding the numbers of red blood cells, white blood cells or platelets were found (Figure $6 a-c)$. Likewise, the levels for the complement complex SC5b-9 as well as for PMN elastase were not altered compared to the negative control where blood without any test specimen was incubated. Moreover, no differences in thrombin-antithrombin-complex (TAT) formation and the platelet activation marker $\beta$-thromboglobulin were detectable between the groups after incubation (Figure $6 \mathrm{~d}-\mathrm{g}$ ). 


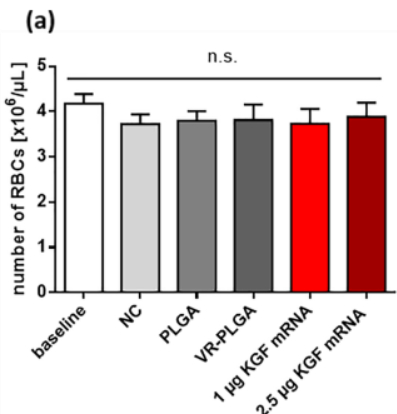

(d)

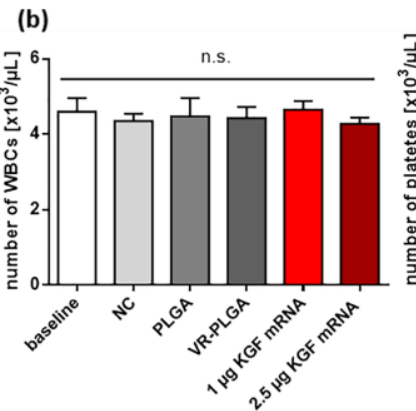

(e)

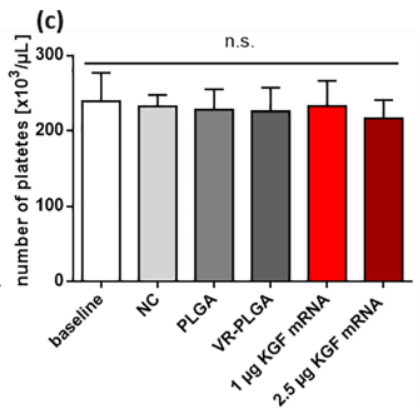

PMN elastase $[\mathrm{ng} / \mathrm{mL}]$
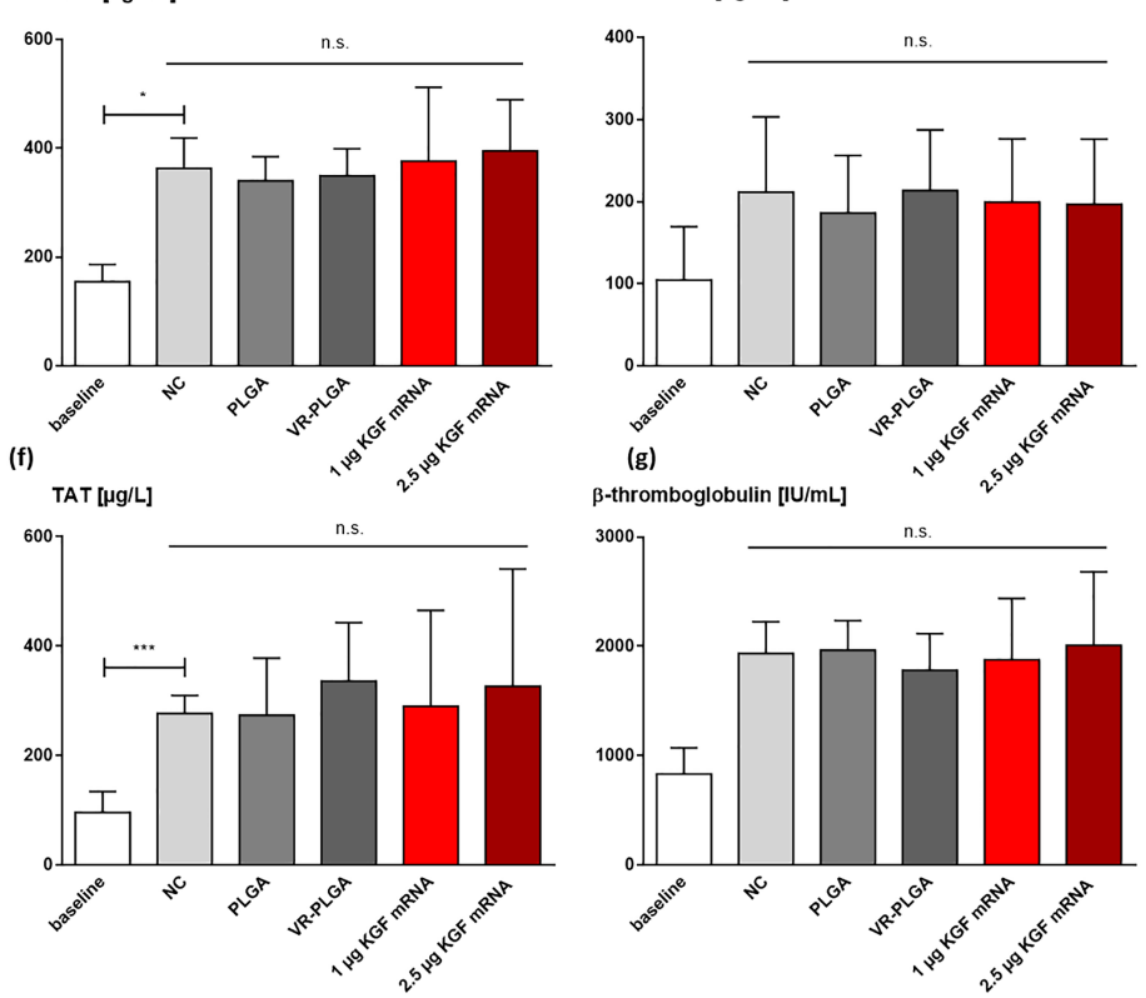

Figure 6. Hemocompatibility testing of sutures coated with PLGA and/ or Viromer RED and KGF mRNA. Numbers of red blood cells (RBCs) (a), white blood cells (WBCs) (b), and platelets per microliter (c) were not altered in all treatment groups. The blood markers for detecting the activation of the complement system (SC5b-9) (d), neutrophil activation (PMN elastase) (e), as well as activation of the clotting cascade (TAT) (f) and platelets ( $\beta$-thromboglobulin) $(\mathrm{g})$ were quantified before and after incubation in blood, using specific ELISA. $\left(n=4 ;{ }^{* *} p<0.001,{ }^{*} p<0.05\right.$, n.s. $=$ not significant $)$.

\section{Discussion}

This study aimed to present a novel approach in the development of bioactive suture material using a polymer-based, mRNA-containing coating, which supports wound regeneration by specific transfection of cells in the wound area. Consequently, through the induced expression of the growth factor KGF, wound healing should be stimulated by the differentiation and proliferation of epithelial cells and the additional mediated anti-apoptotic effect. The results show that polymer-based reagents are more effective in the transfection of cells with mRNA than lipid-based reagents. Most importantly, establishing a mRNA coating based on the biodegradable polymer PLGA with Viromer RED used as transfection reagent has been successful: HEK293 cells, HaCat cells, and primary fibroblasts could be transfected by coated seam material, and the mRNA-PLGA coating even triggered the expression of KGF in HaCat cells, although they do not form this growth factor under physiological conditions [27]. 
Furthermore, the transfection via the coated seam material did not affect the vitality of cells or cause a proinflammatory reaction in the transfected cells. These properties make the mRNA-PLGA coating very attractive for the in vivo application and the hemocompatibility testing, which shows that the suture did not interact with the blood clotting process or complement cascades after an incubation time of $60 \mathrm{~min}$, thereby further qualifying the coating for surgical use. This study established the coating of suture material with mRNA-PLGA complexes to promote the KGF expression at the needed location directly on the sewn wound. This approach guarantees targeted delivery to cells on the skin surface as well as the deeper skin layers with minimal or no loss of therapeutic molecules.

The development of coatings for surgical suture, until now, was mostly targeted at antimicrobial characteristics to prevent surgical site infections using antiseptic agents such as chlorhexidine, natural products such as totarol, or different kinds of silver nanoparticles [28-30]. Additionally, several kinds of drug-eluting sutures have been produced by a variety of manufacturing processes [31]. When it comes to the task of improving wound healing, wound dressings are dominating the market. Moreover, bioactive wound pads seemingly modulate and improve the physiological stages of wound healing [32]. Therefore, products containing collagen and hyaluronic acid are used [33,34]. In addition, another interesting approach to improve wound healing is the use of growth factors due to their immense importance in mediating the wound closure processes. The Becaplermin gel for topical application was released on the market in 1999, containing a recombinant human platelet-derived growth factor (rhPDGF) as its active pharmaceutical ingredient, which showed improved wound healing compared to the placebo in studies [35]. Furthermore, a study by Pierce et al. has shown that the application of $4 \mu \mathrm{g} / \mathrm{cm}^{2}$ recombinant KGF could accelerate wound healing and lead to the formation of a more stable epidermis [36]. Nevertheless, the topical application of growth factors was unsatisfying: Less than $10 \%$ of the applied dose was measurable in superficial layers of the treated granulation tissue and less than $2 \%$ in deeper layers [37]. One idea to overcome this obstacle is gene therapy approaches [38]: Kopp et al. accelerated the healing process of second degree burn wounds by two days through the application of HaCat cells stably expressing KGF after KGF-encoding plasmid transfection [39]. Similarly, electroporative transfection of KGF DNA led to continuous expression of KGF protein and improved wound healing in the treated mice [40].

However, several known disadvantages exist when it comes to DNA-based gene therapy such as the approaching potential mutagenic effect through false integration into the host's genome [41,42]. But this threat does not exist when pursuing a mRNA-based gene therapy approach where the nucleic acid does not enter the nucleus and furthermore the administration of therapeutic mRNA is only temporary and will end when the suture is removed. Moreover, our group recently showed that the application of KGF-encoding mRNA accelerates cell proliferation and migration of keratinocytes in vitro [43]. In order to find out whether it is possible to develop a functional mRNA-containing coating for surgical suture, two different commercially distributed transfection agents were tested in this study: Lipofectamine 2000 and Viromer RED. Here, Lipofectamine 2000 is a mixture of cationic lipids, which forms the supposed lipoplexes when complexing negatively charged mRNA [20]. Furthermore, Viromer RED consists of a polyethyleneimine (PEI) core structure, modified with hydrophobic and anionic side chains, which forms polyplexes with mRNA in aqueous solutions [44]. The results show that only Viromer RED can be used as a transfection agent for mRNA to be incorporated into a PLGA coating. Therefore, when using Lipofectamine 2000, no transfection of cells could be detected. In addition, Abraham et al. described the development of an mRNA-PLGA coating for stents: The group used a protocol in which the mRNA is complexed with Lipofectamine 2000, mixed with a PLGA solution, and applied the coating in layers on Thermanox slides [45]. Consequently, Thermanox is a polyolefin-based polymer gained by polymerization of alkenes and, therefore, has a nonpolar character [46]. The group was able to transfect a significant number of HEK293 cells via this Lipofectamine 2000-based coating. For the present study, multifilament seam material made from polyethylene terephthalate (PET) fibers was used. Accordingly, a PET monomer is a strong polar molecule that carries two carbonyl groups with a positive (carbon) and a negative (oxygen) partial 
charge [47]. Additionally, polymer fibers develop electrostatic charges [48]. Lipofectamine 2000 is formulated by cationic lipids, which form positively charged lipoplexes when complexing mRNA. When cationic lipoplexes are encountered on a polar material such as PET fibers, it is conceivable that their molecular interactions are present in between. Thus, since the integrity and stability of the lipoplexes could be harmed, the mRNA is already released during the coating process. When the coating lacks properly encapsulated mRNA, no cell transfection can occur. In order to avoid this effect, a polymer-based suture material with a non-charged surface-for example, polypropylene (PP)—can be used.

However, the results of this study show that transfection via a mRNA-PLGA coating based on Viromer RED as a transfecting agent leads to efficient protein expression. The transfection efficiency between direct and indirect transfection is comparable as regards the eGFP expression, but unfortunately, the amount of secreted KGF after a transfection via the mRNA-PLGA coating is presently lower compared to the direct transfection. Therefore, to overcome this problem in the future, certain possibilities can help optimize the coating: Viromer RED is a PEI-based transfection agent, which only has limited resistance to ethyl acetate and was used as a solvent for PLGA. This could lead to a decrease in weight and mass after a certain time period [49] and thus make polyplexes lose their stability, thereby leading to a premature mRNA release. In order to bypass this effect and make the transfection via the coating even more efficient, another solvent for PLGA could be used prospectively: The organic ether tetrahydrofuran (THF) works as a solvent for PLGA but, at the same time, does not degrade PEI [50] so the mRNA-loaded polyplexes will not be harmed. Additionally, THF is infinitely soluble in water up to the temperature of $72{ }^{\circ} \mathrm{C}$ [51], which makes the resulting PLGA solution perfectly suitable for the mixture with the water-based mRNA solution and the transfection buffer.

Using the Viromer RED-based mRNA-PLGA coating, encouragingly, it was possible to trigger the expression of the growth factor KGF in HaCat cells, although these cells do not form KGF under physiological conditions. The therapeutically effective level of $4 \mu \mathrm{g}$ KGF mentioned by Pierce et al. was not achieved in the experiments but on the other hand, only $1 \mathrm{~cm}$ of the coated seam material was used. When sewing a cutaneous wound with several stitches, the amount of needed suture exceeds $1 \mathrm{~cm}$ and, therefore, more mRNA will be delivered to the wound territory.

The good cytocompatibility of the mRNA-PLGA coating reflects through the minimal expression of inflammatory markers post transfection: While in the case of direct transfection, the expression of IFN- $\beta$ and TNF- $\alpha$ in BJ fibroblasts significantly increased, cells that were transfected via mRNA-PLGA coating just showed a slightly increased expression of IFN- $\beta$ compared to untreated cells. Consequently, a great advantage of the transfection via the mRNA-PLGA coating is that a gradual mRNA release occurs. It has previously been shown that immune activation through mRNA depends highly on the amount applied to the cells and, additionally, cationic polyplexes themselves are believed to be able to activate TLRs and induce the release of cytokines [52,53]. Therefore, when the coating is degraded piece by piece, the cells are transfected with less encapsulated mRNA at once as compared to direct transfection. In addition, the positive properties of the mRNA-PLGA coating reflect in the results of the hemocompatibility testing where it could be proved that none of the investigated blood parameters was altered by the coated seam material.

In order to deepen the knowledge gained here, further studies need to be carried out: It would be interesting to know how transfection efficiency can be increased by using other solvents or higher amounts of mRNA. The release characteristics of the coating need to be evaluated extensively so that in the next step, the transfection rate can be controlled by the usage of a specially adjusted PLGA. Finally, the use of a skin model or ex vivo testing on human skin is essential for understanding how the mRNA-coated suture can improve the wound healing in detail.

\section{Conclusions}

In conclusion, our work describes a novel approach to support the process of wound healing by mRNA-coated suture materials. For the development of a bioactive suture coating, modified 
mRNA was complexed with Viromer RED and incorporated into a solution of the biodegradable polymer PLGA. The coating enabled the transfection of different cell lines as well as primary cells: The mRNA coating led to both the expression of a functional fluorescent protein as well as of the growth factor KGF. The transfection of cells via the mRNA-PLGA coating was not accompanied by cytotoxic or immunogenic effects in vitro and the results of this study suggest that the performance of the mRNA-PLGA coating can be improved even further by using other solvents for the coating solution. The excellent cytocompatibility of the coated seam material indicates that even higher amounts of mRNA could be incorporated.

To our knowledge, the present study describes, for the first time, the development of an mRNA-based suture coating aiming to transfect cells in the wound area and thus improve wound healing, which would also be of particular interest in other fields of wound management.

Author Contributions: Conceptualization, A.L. and S.K.; Methodology, A.L. and H.H.; Software, A.L. and H.H.; Validation, S.K., M.D., and T.M.; Formal Analysis, T.M.; Investigation, A.L.; Resources, S.K. and M.D.; Data Curation, M.D.; Writing—Original Draft Preparation, A.L.; Writing—Review and Editing, T.M., S.K., M.D., H.H., C.S., and H.P.W.; Visualization, A.L., T.M., and S.K.; Supervision, S.K.; Project Administration, H.P.W.; Funding Acquisition, S.K.

Funding: We acknowledge support by Deutsche Forschungsgemeinschaft and Open Access Publishing Fund of University of Tuebingen.

Acknowledgments: We thank Ernst Schweizer form the section of medical materials science \& technology of the University Hospital Tuebingen for assistance with scanning electron microscopy.

Conflicts of Interest: The authors declare no conflict of interest.

\section{References}

1. Boateng, J.; Catanzano, O. Advanced therapeutic dressings for effective wound healing-A review. J. Pharm. Sci. 2015, 104, 3653-3680. [CrossRef] [PubMed]

2. Stuecker, M.; Harke, K.; Rudolph, T.; Altmeyer, P. Pathogenesis of therapy refractory ulcus cruris. Der Hautarzt 2003, 54, 750-755. [CrossRef] [PubMed]

3. Menke, N.B.; Ward, K.R.; Witten, T.M.; Bonchev, D.G.; Diegelmann, R.F. Impaired wound healing. Clin. Dermatol. 2007, 25, 19-25. [CrossRef] [PubMed]

4. Werner, S.; Grose, R. Regulation of wound healing by growth factors and cytokines. Physiol. Rev. 2003, 83, 835-870. [CrossRef] [PubMed]

5. Lippert, H. Wundatlas; Georg Thieme Verlag: Stuttgart, Germany, 2012.

6. Gokarneshan, N.; Velumani, K. Recent innovations in textile sutures-An approach towards improved surgical procedures. Sci. J. Biomed. Eng. Biomed. Sci. 2018, 2, 001-007.

7. Firestone, D.E.; Lauder, A.J. Chemistry and mechanics of commonly used sutures and needles. J. Hand Surg. Am. 2010, 35, 486-488. [CrossRef] [PubMed]

8. Reckhenrich, A.K.; Kirsch, B.M.; Wahl, E.A.; Schenck, T.L.; Rezaeian, F.; Harder, Y.; Foehr, P.; Machens, H.-G.; Egaña, J.T. Surgical sutures filled with adipose-derived stem cells promote wound healing. PLoS ONE 2014, 9, e91169. [CrossRef] [PubMed]

9. Saxena, S.; Ray, A.R.; Kapil, A.; Pavon-Djavid, G.; Letourneur, D.; Gupta, B.; Meddahi-Pellé, A. Development of a new polypropylene-based suture: plasma grafting, surface treatment, characterization, and biocompatibility studies. Macromol. Biosci. 2011, 11,373-382. [CrossRef] [PubMed]

10. Viju, S.; Thilagavathi, G. Effect of chitosan coating on the characteristics of silk-braided sutures. J. Ind. Text. 2013, 42, 256-268. [CrossRef]

11. Liu, H.; Ge, Z.; Wang, Y.; Toh, S.L.; Sutthikhum, V.; Goh, J.C.H. Modification of sericin-free silk fibers for ligament tissue engineering application. J. Biomed. Mater. Res.-Part B Appl. Biomater. 2007, 82, 129-138. [CrossRef] 
12. Beer, H.D.; Gassmann, M.G.; Munz, B.; Steiling, H.; Engelhardt, F.; Bleuel, K.; Werner, S. Expression and function of keratinocyte growth factor and activin in skin morphogenesis and cutaneous wound repair. $J$. Investig. Dermatol. Symp. Proc. 2000, 5, 34-39. [CrossRef] [PubMed]

13. Koziak, K.; Bojakowska, M.; Robson, S.C.; Bojakowski, K.; Soin, J.; Csizmadia, E.; Religa, P.; Gaciong, Z.; Kaczmarek, E. Overexpression of CD39/nucleoside triphosphate diphosphohydrolase-1 decreases smooth muscle cell proliferation and prevents neointima formation after angioplasty. J. Thromb. Haemost. 2008, 6, 1191-1197. [CrossRef] [PubMed]

14. Avci-Adali, M.; Behring, A.; Keller, T.; Krajewski, S.; Schlensak, C.; Wendel, H. Optimized conditions for successful transfection of human endothelial cells with in vitro synthesized and modified mRNA for induction of protein expression. J. Biol. Eng. 2014, 8, 8. [CrossRef] [PubMed]

15. Sahin, U.; Karikó, K.; Türeci, Ö. mRNA-based therapeutics-Developing a new class of drugs. Nat. Rev. Drug Discov. 2014, 13, 759-780. [CrossRef] [PubMed]

16. Pardi, N.; Hogan, M.J.; Porter, F.W.; Weissman, D. mRNA vaccines-A new era in vaccinology. Nat. Rev. Drug Discov. 2018, 17, 261-279. [CrossRef] [PubMed]

17. Washbourne, P.; McAllister, A.K. Techniques for gene transfer into neurons. Curr. Opin. Neurobiol. 2002, 12, 566-573. [CrossRef]

18. Boussif, O.; Lezoualc’h, F.; Zanta, M.A.; Mergny, M.D.; Scherman, D.; Demeneix, B.; Behr, J.P. A versatile vector for gene and oligonucleotide transfer into cells in culture and in vivo: Polyethylenimine. Proc. Natl. Acad. Sci. USA 1995, 92, 7297-7301. [CrossRef]

19. Cardarelli, F.; Digiacomo, L.; Marchini, C.; Amici, A.; Salomone, F.; Fiume, G.; Rossetta, A.; Gratton, E.; Pozzi, D.; Caracciolo, G.; et al. The intracellular trafficking mechanism of Lipofectamine-based transfection reagents and its implication for gene delivery. Sci. Rep. 2016, 6, 25879. [CrossRef]

20. Kim, T.K.; Eberwine, J.H. Mammalian cell transfection: The present and the future. Anal. Bioanal. Chem. 2010, 397, 3173-3178. [CrossRef]

21. Choi, C.H.J.; Hao, L.; Narayan, S.P.; Auyeung, E.; Mirkin, C.A. Mechanism for the endocytosis of spherical nucleic acid nanoparticle conjugates. Proc. Natl. Acad. Sci. USA 2013, 110, 7625-7630. [CrossRef]

22. Liechty, W.B.; Kryscio, D.R.; Slaughter, B.V.; Peppas, N.A. Polymers for drug delivery systems. Annu. Rev. Chem. Biomol. Eng. 2010, 1, 149-173. [CrossRef] [PubMed]

23. Sadat Tabatabaei Mirakabad, F.; Nejati-Koshki, K.; Akbarzadeh, A.; Yamchi, M.R.; Milani, M.; Zarghami, N.; Zeighamian, V.; Rahimzadeh, A.; Alimohammadi, S.; Hanifehpour, Y.; et al. PLGA-based nanoparticles as cancer drug delivery systems. Asian Pac. J. Cancer Prev. 2014, 15, 517-535. [CrossRef] [PubMed]

24. Hu, C.; Feng, H.; Zhu, C. Preparation and characterization of rifampicin-PLGA microspheres/sodium alginate in situ gel combination delivery system. Colloids Surf. B Biointerfaces 2012, 95, 162-169. [CrossRef] [PubMed]

25. Marquette, S.; Peerboom, C.; Yates, A.; Denis, L.; Langer, I.; Amighi, K.; Goole, J. Stability study of full-length antibody (anti-TNF alpha) loaded PLGA microspheres. Int. J. Pharm. 2014, 470, 41-50. [CrossRef] [PubMed]

26. Barrientos, S.; Stojadinovic, O.; Golinko, M.S.; Brem, H.; Tomic-Canic, M. Growth factors and cytokines in wound healing. Wound Repair Regen. 2008, 16, 585-601. [CrossRef]

27. Kujath, P.; Michelsen, A. Wounds-From physiology to wound dressing. Deutsches Ärzteblatt Int. 2008, 105, 239-248. [CrossRef] [PubMed]

28. Reinbold, J.; Uhde, A.-K.; Müller, I.; Weindl, T.; Geis-Gerstorfer, J.; Schlensak, C.; Wendel, H.-P.; Krajewski, S.; Reinbold, J.; Uhde, A.-K.; et al. Preventing surgical site infections using a natural, biodegradable, antibacterial coating on surgical sutures. Molecules 2017, 22, 1570. [CrossRef]

29. Obermeier, A.; Schneider, J.; Harrasser, N.; Tübel, J.; Mühlhofer, H.; Pförringer, D.; von Deimling, C.; Foehr, P.; Kiefel, B.; Krämer, C.; et al. Viable adhered Staphylococcus aureus highly reduced on novel antimicrobial sutures using chlorhexidine and octenidine to avoid surgical site infection (SSI). PLoS ONE 2018, 13, e0190912. [CrossRef]

30. Chandrasekaran, N.; Dhas, S.; Anbarasan, S.; Mukherjee, A. Biobased silver nanocolloid coating on silk fibers for prevention of post-surgical wound infections. Int. J. Nanomed. 2015, 10, 159. [CrossRef] 
31. Champeau, M.; Thomassin, J.-M.; Tassaing, T.; Jérôme, C. Current manufacturing processes of drug-eluting sutures. Expert Opin. Drug Deliv. 2017, 14, 1293-1303. [CrossRef]

32. Heinlin, J.; Schreml, S.; Babilas, P.; Landthaler, M.; Karrer, S. [Cutaneous wound healing. Therapeutic interventions]. Der Hautarzt 2010, 61, 611-628. [CrossRef] [PubMed]

33. Frieß, W.; Metzmacher, I.; Wild, T. Die Bedeutung von Kollagen und Kollagenasen in der Wundheilung. In Manual der Wundheilung; Springer: Vienna, Austria, 2007; pp. 89-97.

34. Goa, K.L.; Benfield, P. Hyaluronic acid. A review of its pharmacology and use as a surgical aid in ophthalmology, and its therapeutic potential in joint disease and wound healing. Drugs 1994, 47, 536-566. [CrossRef] [PubMed]

35. Wieman, T.J.; Smiell, J.M.; Su, Y. Efficacy and safety of a topical gel formulation of recombinant human platelet-derived growth factor-BB (becaplermin) in patients with chronic neuropathic diabetic ulcers. A phase III randomized placebo-controlled double-blind study. Diabetes Care 1998, 21, 822-827. [CrossRef] [PubMed]

36. Pierce, G.F.; Yanagihara, D.; Klopchin, K.; Danilenko, D.M.; Hsu, E.; Kenney, W.C.; Morrisg, C.F. Stimulation of all epithelial elements during skin regeneration by keratinocyte growth factor. J. Exp. Med. 2004, 179, 831-840. [CrossRef] [PubMed]

37. Singer, A.J.; Clark, R.A.F. Cutaneous wound healing. N. Engl. J. Med. 1999, 341, 738-746. [CrossRef] [PubMed]

38. Branski, L.K.; Gauglitz, G.G.; Herndon, D.N.; Jeschke, M.G. A review of gene and stem cell therapy in cutaneous wound healing. Burns 2009, 35, 171-180. [CrossRef] [PubMed]

39. Kopp, J.; Wang, G.Y.; Kulmburg, P.; Schultze-Mosgau, S.; Huan, J.N.; Ying, K.; Seyhan, H.; Jeschke, M.D.; Kneser, U.; Bach, A.D.; et al. Accelerated wound healing by in vivo application of keratinocytes overexpressing KGF. Mol. Ther. 2004, 10, 86-96. [CrossRef] [PubMed]

40. Marti, G.; Ferguson, M.; Wang, J.; Byrnes, C.; Dieb, R.; Qaiser, R.; Bonde, P.; Duncan, M.D.; Harmon, J.W. Electroporative transfection with KGF-1 DNA improves wound healing in a diabetic mouse model. Gene Ther. 2004, 11, 1780-1785. [CrossRef] [PubMed]

41. Youn, H.; Chung, J.-K. Modified mRNA as an alternative to plasmid DNA (pDNA) for transcript replacement and vaccination therapy. Expert Opin. Biol. Ther. 2015, 15, 1337-1348. [CrossRef]

42. Michel, T.; Wendel, H.-P.; Krajewski, S. Next-Generation Therapeutics: mRNA as a Novel Therapeutic Option for Single-Gene Disorders. In Modern Tools for Genetic Engineering; InTech: London, UK, 2016; ISBN 978-953-51-2234-0.

43. Denzinger, M.; Link, A.; Kurz, J.; Krauss, S.; Thoma, R.; Schlensak, C.; Wendel, H.P.; Krajewski, S. Keratinocyte growth factor modified messenger RNA accelerating cell proliferation and migration of keratinocytes. Nucleic Acid Ther. 2018, 28, 335-347. [CrossRef]

44. Panzner, S. Transfection: Viral and Synthetic Techniques Converge. Genet. Eng. Biotechnol. News 2014, 34, 20-21. [CrossRef]

45. Abraham, M.K.; Nolte, A.; Reus, R.; Behring, A.; Zengerle, D.; Avci-Adali, M.; Hohmann, J.D.; Peter, K.; Schlensak, C.; Wendel, H.P.; et al. In vitro study of a novel stent coating using modified CD39 messenger RNA to potentially reduce stent angioplasty-associated complications. PLoS ONE 2015, 10, e0138375. [CrossRef] [PubMed]

46. White, J.L.; Choi, D.D. Polyolefins: Processing, Structure Development and Properties; Hanser: Cincinnati, $\mathrm{OH}$, USA, 2005.

47. Franck, A.; Herr, B.; Ruse, H.; Schulz, G. Kunststoff-Kompendium; Vogel Business Media: Würzburg, Germany, 2011; ISBN 3834331643.

48. Zeltobrjuchov, V.F. Elektrostatische Aufladung von Fasern und Moglichkeiten zu ihrer Beseitigung. Fortschrittsbericht. Acta Polym. 1982, 33, 447-453. [CrossRef]

49. Ludwick, A.G.; Overberger, C.G. Synthesis and characterization of polyethylenimine backbone polynucleotide models. J. Polym. Sci. Polym. Chem. Ed. 2003, 20, 2123-2138. [CrossRef]

50. Gentile, P.; Chiono, V.; Carmagnola, I.; Hatton, P. An Overview of Poly(lactic-co-glycolic) Acid (PLGA)-Based Biomaterials for Bone Tissue Engineering. Int. J. Mol. Sci. 2014, 15, 3640-3659. [CrossRef] [PubMed]

51. Matouš, J.; Hrnčiřík, J.; Novák, J.P.; Šobr, J. Liquid-liquid equilibrium in the system water-tetrahydrofuran. Collect. Czechoslov. Chem. Commun. 1970, 35, 1904-1905. [CrossRef] 
52. Masotti, A.; Mossa, G.; Cametti, C.; Ortaggi, G.; Bianco, A.; Del Grosso, N.; Malizia, D.; Esposito, C. Comparison of different commercially available cationic liposome-DNA lipoplexes: Parameters influencing toxicity and transfection efficiency. Colloids Surf. B Biointerfaces 2009, 68, 136-144. [CrossRef]

53. Zolnik, B.S.; González-Fernández, Á.; Sadrieh, N.; Dobrovolskaia, M.A. Minireview: Nanoparticles and the immune system. Endocrinology 2010, 151, 458-465. [CrossRef]

(C) 2019 by the authors. Licensee MDPI, Basel, Switzerland. This article is an open access article distributed under the terms and conditions of the Creative Commons Attribution (CC BY) license (http://creativecommons.org/licenses/by/4.0/). 